\title{
Serology for human papillomavirus
}

Pierre Coursaget, Pharm D.(1)

\begin{abstract}
Coursaget $P$.
Serology for human papillomavirus. Salud Publica Mex 2003;45 suppl 3:S361-S366. This paper is available too at: http://www.insp.mx/salud/index.html
\end{abstract}

\begin{abstract}
A bstract
Difficulties with serology for papillomavirus are associated with the large number of human papillomavirus, crossreactions between papillomavirus, and to the diversity of lesions and target sites for infection. In addition, the expression of the papillomavirus in the superficial layers of the epithelium gives rise to the weak presentation to immuno competent cells of viral antigens, which in turn gives rise to a weak serological response. Distinct efforts have been made in previous decades to develop more specific and sensitive serological assays. These former studies use fusion proteins and synthetic peptides, although they remain on the whole uninteresting, due to their lack of sensitivity and specificity. 0 nly in the last few years, and principally due to the advent of various virus-like particles (VLP), have more sensitive and specific assays become available. This paper is available too at:http://www.insp.mx/salud/index.html
\end{abstract}

Key words: cervical cancer;VLP; HPV; serology

\section{Coursaget $\mathbf{P}$. \\ Serología para el virus del papiloma humano. \\ Salud Publica Mex 2003;45 supl 3:S361-S366. \\ Este artículo también está disponible en: http://www.insp.mx/salud/index.html}

\section{Resumen}

Las limitaciones para la utilización de la serología para el estudio del virus del papiloma humano con fines clínicos están aso ciadas con la gran variedad de subtipos humanos, con las reacciones cruzadas que existen entre diversos genotipos, la diversidad de lesiones precursoras de cáncer y con los sitios blancos de infección. A simismo, la expresión del virus del papiloma humano en las capas superficiales del epitelio dan origen a una débil presentación de células inmuno competentes de antígenos virales, lo cual origina una elevación de la respuesta serológica. D istintos esfuerzos se han realizado en décadas previas para desarrollar ensayos serológicos más específicos y sensibles. En muchas investigaciones se ha utilizado una fusión de proteínas y péptidos sintéticos que tienen como principal limitación su escasa sensibilidad y especificidad. Sólo en los últimos años, y principalmente debido al arribo de partículas parecidas a este virus, tenemos disponibles ensayos más sensibles y específicos, ampliamente descritos en este artículo. Este artículo también está disponible en: http://www.insp.mx/ salud/index.html

Palabras clave:cáncer cervical;VLP;virus de papiloma humano; serología

\section{Antibodies directed against non-structural proteins}

Detection of antibodies directed against the nonstructural proteins E2 and E4 has been possible using fusion and synthetic proteins. ${ }^{1-3}$ Antibodies against E2 protein can be detected in $2 / 3$ viral DNA positive subjects. ${ }^{4}$ A study which used $\mathrm{E} 2$ produced in insect cells indicates that there is a correlation between the detection of anti-E2 IgA and severity of lesions, although these antibodies disappear over the course of neoplasia evolution. ${ }^{5}$ Unfortunately, the sensitivity and specificity

(1) Laboratoire de Virologie Moléculaire, Faculté de Pharmacie Ph. Maupas, Tours, France.

Received on: September 17,2002 • Accepted on: January 15, 2003

Address reprint requests to: Dr. Pierre Coursaget. Laboratoire de Virologie Moléculaire, Faculté de Pharmacie Ph Manupas,

31 Avenue Monge, 37200 Tours, France.

E-mail: coursaget@ univ-tours.fr 
of these assays have been evaluated in only a handful of studies. Given that there is a strong upregulation of E4 production throughout the viral cycle, anti-E4 antibody has been proposed as a marker for viral replication. ${ }^{6,7}$ Nevertheless, results have been inconsistent, some studies reporting several percent to $40 \%$ of positive anti-E4 subjects. ${ }^{8}$

It is generally accepted that E6 and E7 are produced in large quantities in cancerous cells. Consequently, anti-E6 and anti-E7 antibodies have been associated with malignant progression of the disease, and their detection is optimum in patients with cancer of the cervix. ${ }^{9-11}$ These results have been confirmed using synthetic peptides, and proteins translated in vitro or proteins produced from a baculovirus/insect cell system. ${ }^{11-17}$ The studies using recombinant proteins for antigen have shown that anti-E6 and E7 antibodies are detected in $50 \%$ to $60 \%$ of patients with cervical uterine cancer. ${ }^{18}$ However, not all patients are positive, and the prognostic value for detection of anti-E6 and anti-E7 antibodies is, according to the authors, either very limited or nil. 10,15,19 The absence of immune response to these antigens does not appear to be associated with the existence of antigenic variants. ${ }^{17}$

\section{Antibodies directed against structural proteins}

In vitro culture of the virus depends on the genotype, either impossible, or too weak, and the quantity of virions present in lesions is generally too low to be used as an antigenic source. The only exception has been the preparation of HPV1 virions using plant warts, and their use for serological assays. ${ }^{20,21}$ Expression of structural

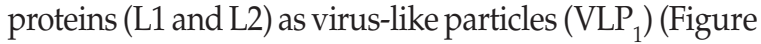
1) has stimulated the development of more sensitive assays to measure immune response to the infection. ${ }^{22}$ VLP production has been achieved in several eukaryotic expression systems, including baculovirus/insect cells, vaccinia virus, Semliki forest virus, and yeast.22,23 These VLPs, composed of either only L1, or L1 with L2, are similar morphologically, in size, and in conformational epitopes to virions. ${ }^{24-26}$

\section{Detection of anti-VLPS}

VLPs are currently available for more than a dozen genital papillomavirus and five cutaneous papillomavirus. The most widely used technique uses VLP ${ }_{1}$ bound to a solid support to bind serum antibody which is detected using a marked second anti-human antibody. The low sensitivity of these assays is due primarily to a weak natural immune response, rather than to poor quality antigen or assay. In order to improve specificity, one can use a binding inhibition assay using a monoclonal antibody which recognizes the major conformational epitope of $\mathrm{L} 1 .{ }^{27} 75 \%$ to $80 \%$ of positive anti-VLP sera react with this epitope, and the majority of anti-VLP activity is directed against this epitope. However, certain subjects develop antibody to other epitopes, which means that they will not be detected with such assay. One other option to improve the specificity of assays is to neutralize anti-VLP antibody binding through pre-incubation with different VLPs followed by antibody detection. ${ }^{28}$ These more laborious assays allow one to differentiate between specific and cross-reactive binding.

\section{Humoral anti-VLP response}

The anti-VLP response is type specific, despite cross reactivity with closest genotypes. ${ }^{29-33}$ Evidence to support this includes the fact that anti-VLP antibodies are weakly or not present in virgin women ${ }^{34-36}$ or young children. ${ }^{33,37}$ The different variants for genotype 16 correspond to one serotype. ${ }^{38-40}$

Nonetheless, there are cross reactions among phylogenetically similar papillomavirus. ${ }^{30,32,33,41-44}$ This has been observed between HPV 6 and $11^{45-48}$ and between HPV 18 and $45 .^{49}$ In addition, multiple cross reactions have been observed in a highly infected population, using seven genital papillomavirus. ${ }^{33}$ Significant cross reactions have been observed between genotypes 6 and 11 (group A10), among 16, 31, 33 and

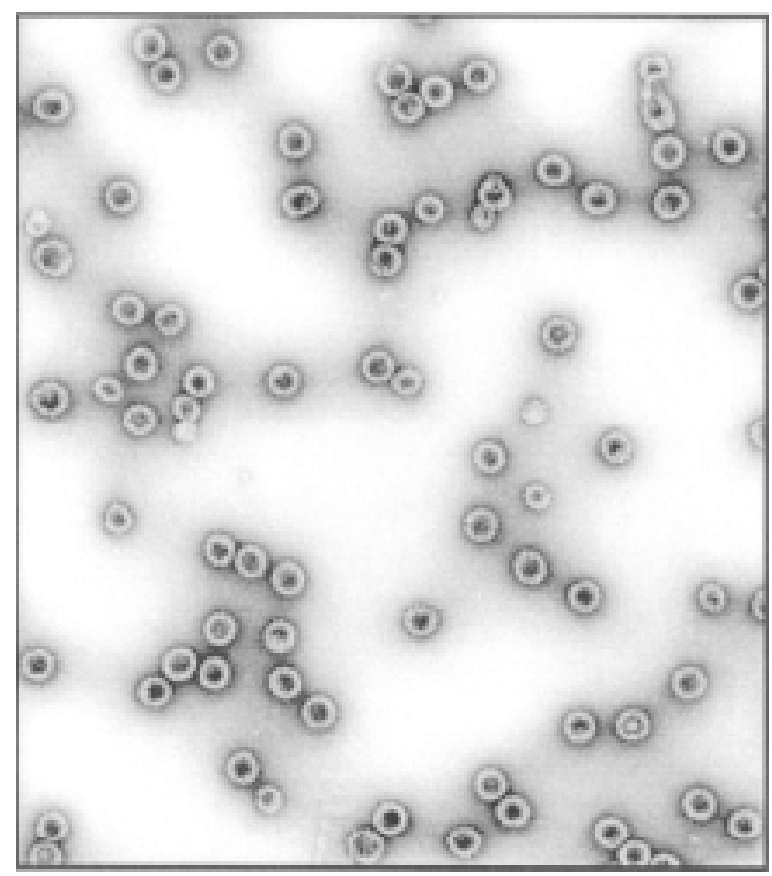

Figure 1. ELECTRON Microscopy OF HPV 31VLPs USED AS ANTIGEN IN ELISA TEST. 
58 (group A9), and among 18, 39, 45 and 59 (group A7). It is therefore difficult to determine whether an infection is due to the test genotype or one or more of its closest genotypes.

The kinetics of anti-VLP antibody appearance is now better understood. Antibodies are found in 10 to $20 \%$ of infected individuals at the time that DNA is detectable, 1 to 3 months after infection. Prospective studies ${ }^{34,50-54}$ indicate that 70 to $90 \%$ of HPV 16-infected women seroconvert approximately eight months after DNA appearance. Later seroconversions may occur at 18 months, while these studies also suggest that anti-VLP antibody are always detectable in following years. ${ }^{55}$ However, anti-VLP antibodies do not appear to persist several years after infection, and in fact seroepidemiological data indicate that they disappear with age. ${ }^{36}$

Over the course of an infection, anti-VLP antibody may appear before the lesion. ${ }^{51,56,57}$ Anti-VLP seropositivity is also associated with lesion persistence. Approximately $80 \%$ of women who have persisting HPV-DNA, develop anti-VLP antibody although they are detected in only $22 \%$ of women who develop a transitory infection. ${ }^{56}$

Numerous studies have been conducted regarding anti-VLP antibody detection in high risk genital papillomavirus. ${ }^{58}$ Anti- HPV 16 capsid serum IgG is detected in 50 to $60 \%$ of women positive for type 16 papillomavirus DNA, and between 5 and $20 \%$ of control subjects. ${ }^{51,59-61}$

Detection of anti-VLP antibody is also associated with the severity of lesions. ${ }^{58}$ Anti-HPV 16 antibodys are detected in approximately $30 \%$ of patients with a low grade 'SIL', approximately $50 \%$ of severe lesions, and in 50 to $80 \%$ of cancers. ${ }^{61-63}$ Nonetheless, anti-VLP antibody detection is less discriminatory than viral DNA detection. Prospective studies ${ }^{50,52,53}$ also demostrate that anti-VLP IgG detection is more prevalent in women whose infection evolves to severe lesions, and is associated with a higher risk of developing cervical cancer. ${ }^{52,64}$ Therefore, during a non-persistent infection only a low percentage of subjects develop anti-VLP antibody. ${ }^{65}$ Production of anti-VLP antibody is not a sign of healing ${ }^{53}$ and in addition, detection of anti-VLP antibodies has no prognostic values for the evolution of cervical cancer. 19,33

Two factors influence the frequency of anti-VLP antibody detection: Sexual activity, and co-infection with HIV virus. Seroprevalence is higher in women than in men. ${ }^{66,67}$ This difference may be explained by the higher rate of persistent infection in women following a contaminating sexual contact. It is also recognized that papillomavirus DNA is found more frequently in subjects positive for HIV virus. However, seroprevalence in prostitutes positive and negative for HIV virus have been reported to be the same. ${ }^{68}$ Other studies using open population or cancer patients have found a higher prevalence of anti-VLP antibody in HIV positive subjects. ${ }^{69,70}$

Significance of anti-viral capsid antibody

Serological assays for anti-VLP have no diagnostic value. Many patients who are negative for viral DNA may have been infected in previous months or years. A serological assay would be useful for this type of unapparent infection. Nonetheless, as seroconversion is slow, some subjects may be anti-VLP negative several months after the disappearance of viral DNA. In addition, during a transitory infection, only 20 to $25 \%$ of subjects develop anti-VLP antibody. Kjaer and colleagues ${ }^{71}$ found that lesions were not observed in recently infected subjects despite quickly developing anti-VLP antibodies. Although these studies were conducted on few subjects, they suggest that the appearance of anti-VLP antibody during the acute phase of the disease would be a sign of healing.

The body of evidence suggests that neutralizing antibodies are not, as in other viral diseases, a sign of healing, nor of protection against a re-infection, rather that they are the sign of a persistent replication and are particularly found in cancers associated with papillomavirus. During a natural infection, anti-viral capsid antibody titres are weak. In contrast, after antipapillomavirus vaccination, anti-VLP antibody levels are high.

During persistent or chronic infections, an anti-VLP serological response develops in many subjects, and the prevalence of detection is positively correlated with the time course of the infection. However, antibody presence in a viral DNA carrier does not appear to be a prognostic marker. Subjects with cervical cancer and who have antiVLP antibody have identical follow up to those without antibody, if age and size of tumors are adjusted. ${ }^{33}$

Seroreactivity for high risk HPV is clearly a marker for sexual activity. Seroreactivity increases with total number of sexual partners. ${ }^{72}$ Seroprevalence in prostitutes is 10 to 14 times higher than in the general population. ${ }^{35}$ Anti-VLP antibody is a more recent marker than viral DNA, which can be used in epidemiological studies to establish or confirm the role of these virus in different cancers. ${ }^{73-75}$ However, relative risk (OR) obtained via serology are on the order of 2 to 6 , while values of 30 to several hundred are observed for DNA detection. ${ }^{76}$ For studies on risk factors associated with infection, viral DNA detection or serology are markers with equivalent value. ${ }^{36}$

Anti-VLP antibody detection is a tool to confirm the etiological role of papillomavirus. The study of 
seroprevalence in different cancers is, depending on the study, to verify viral etiology for cervical, anal, vulval cancers, as well as cancer of the penis. ${ }^{41,70,73-75,77,78}$ The primary interest in studying anti-VLP antibodies is to measure infection prevalence in a given population, or to study risk associated with repeated infections in a same individual. The presence of anti-VLP antibody in viral DNA negative subjects is correlated with an elevated number of sexual partners. ${ }^{34,35,79}$ However, the presence of anti-VLP antibodies in certain young women and in children, suggests that other than sexual modes of transmission probably exist. Reactivity in these populations may be due to cross reactivity with cutaneous papillomavirus, or the existence of a genital papillomavirus infection of the oral cavity. ${ }^{80,81}$

\section{Conclusion}

The body of data regarding anti-papillomavirus serology demonstrates that anti-VLP antibody detection is the only reliable serological marker. Anti-VLP antibody is largely type specific, although cross reactions occur in less than $10 \%$ of assays. Each genotype corresponds to one serotype, and it has not yet been shown whether two different genotypes can belong to a same serotype. However, the detection of anti-VLP antibodies is not a reliable assay for diagnosis, since antibody detection is strongly asynchronous with infection and is rarely the sign of healing. Serological results suggest that antiVLP antibodies are detected primarily in association with persistent replication, and that these antibodies decrease rapidly, particularly following a non-persistent infection. In addition, these antibodies are not always present and do not persist in all infected subjects. They are therefore not a good marker of older infection. The principal application of anti-papillomavirus serology should be in years to come, that of monitoring antipapillomavirus vaccination.

\section{References}

1. Banks L, Matlashewski G, Pim D, Churcher M, Roberts C, Crawford L. Expression of human papillomavirus type 6 and type 16 capsid proteins in bacteria and their antigenic characterization.J GenVirol 1987;68:3081-3089. 2. Li CC, Shah KV, Seth A, G ilden RV. Identification of human papillomavirus type $6 \mathrm{~b}$ open reading frame protein and corresponding antibodies in human sera. J Virol 1987;61:2684-2690.

3. C ason J, Kambo PK, Best JM, McC ance DJ. D etection of antibodies to a linear epitope on the major coat protein (L1) of human papillomavirus type 16 (HPV16) in sera from patients with cervical intraepithelial neoplasia and in children. Int J C ancer 1992;50:349-355.

4. Rosales R, López-Contreras M, Cortés RR. Antibodies against human papillomavirus (HPV) type 16 and 18 E2,E6 and E7 proteins in sera:Correlation with presence of papillomavirus DN A.J MedVirol 2001;65:736-744

5. Rocha-Zavaleta L, Jordan D, Pepper S, C orbitt G, Clarke F, Maitland N J et al. Difference in serological IgA responses to recombinant baculovirusderived human papillomavirus E2 protein in the natural history of cervical neoplasia. Br J Cancer 1997;75:1144-1150.

6. Müller M, Gissmann L, C ristiano R, Sun X, Frazer I, Jenson A et al. Papillomavirus capside binding and uptake by cells from differents tissues and species. J virol 1995;69:948-954.

7. Dillner J. Serology of human papillomavirus. Cancer J 1997;8:264-269. 8. KandaT, 0 nzaT,Zanma S,Yasugi T, Furuno $A$, W atanabe $S$ et al. Independent association of antibodies against human papillomavirus type $16 \mathrm{E} 1 / \mathrm{E} 4$ and E7 proteins with cervical cancer.Virology 1992;190:724-732. 9. Dillner J. Mapping of linear epitopes of human papillomavirus type 16:The E1, E2, E4, E6 and E7 open reading frames. Int J C ancer 1990;46:703-711.

10. Mann VM, de Lao SL, Brenes M, Brinon LA, Rawis JA, Green M et al. 0 ccurrence of IgA and IgG antibodies to select peptides representing human papillomavirus type 16 among cervical cancer cases and controls. Cancer Res 1990;50:7815-7819.

11. Müller M,Viscidi RP, Sun Y, G uerrero E, Hill PM, Shah F et al.Antibodies to H PV-16 E6 and E7 proteins as masrkers for H PV-16 associated invasive cervical cancer.Virology 1992;187:508-514.

12. Jochmus-Kudielka I, Schnider A, Braun R, Kimmig R, Koldovsky U, Schneweis $K E$ et al. Antibodies against the human papillomavirus type 16 early proteins in human sera:C Correlation of anti-E7 reactivity with cervical cancer.J N atl C ancer Inst 1989;81:1698-1704.

13. Bleul C, Müller M, Frank R, Gausepohol U, Mgaya HN, Luane J et al. Human papillomavirus type $18 \mathrm{E} 6$ and $\mathrm{E} 7$ antibodies in human sera: Increased anti-E7 prevalence in cervical cancer patients. J C lin Microbiol 191;29:1579-1588.

14. Viscidi RP, Sun Y, Tsuzaki B, Bosch FX, Muñoz N, Shah KV. Serologic response in human papillomavirus-associated invasive cervical cancer. Int J Cancer 1993:55:780-784.

15. Gaarenstroom KM, Kenter G G, Bonfrer JM, Korse CM, Galle MP, Hart $A A$ et al. Prognostic significance of serum antibodies to human papillomavirus-16 E4 and E7 peptides in cervical cancer. Cancer 1994;74:2307-2313.

16. Hamsikova E, N ovack J, HofmannovaV, Muñoz N , Bosch FX, D e Sanjosé $S$ et al. Presence of antibodies to seven human papillomavirus type-16derived peptides in cervical cancer patients and healthy controls. J Infect Dis 1994;170:1424-1431.

17. N indl I, Zumbach K, Pawlita M, Teller K, Scheinder A, D urst M.Absence of antibody against human papillomavirus type $16 \mathrm{E} 6$ and $\mathrm{E} 7$ in patients with cervical cancer is independent of sequence variations. I Infect $D$ is 2000;181:1764-1767.

18. MeschedeW,Zumbach K, Braspenning J,Scheffner M, Benítez-Bribiesca $L$ et al. Antibodies against early proteins of human papillomavirus as diagnostic markers for invasive cervical cancer. J Clin Microbiol 1998:36:475-480.

19. Silins I,Avall-Ludqvist E,Tadesse A, Jansen KU, Stgendahl U, Lenner P et al. Evaluation of antibodies to human papillomavirus as prognostic markers in cervical cancer patients. Gynecol 0 ncol 2000;85:333-338.

20. Steele JC, Gallimore PH. Humoral assays of human sera to disrupted and non-disrupted epitopes of papillomavirus type 1. Virology 1990;174:388-398.

21.Viac J, C homel JJ, C hardonnet Y,Aymard M. Incidence of antibodies to human papillomavirus type 1 in patients with cutaneous and mucosal papillomavirus. J Med Virol 1990; 21:18-21.

22. Schiller JT, Roden RB. Papillomavirus-like particles. Papillomavirus Rep 1995;6:121-128.

23. Schiller JT, Lowry DR. Papillomavirus-like particles and HPV vaccine development. Cancer Biol 1996;7:373-382.

24. Kirnbauer R,Taub J, G reenstone H, Roden R, D urst M, G issmann L et al. Efficient self-assembly of human papillomavirus type $16 \mathrm{~L} 1$ and $L 2$ into virus like particles. J Virol 1993;67:6929-6936. 
25. Hagensee ME, Yaegashi N, Galloway DA. Self-assembly of human papillomavirus type 1 capsids by expression of the L1 protein alone or by the L1 and L2 capsid proteins. JVirol 1993;67:315-322.

26. Hagansee ME, O Ison N H, Baker TS, Galloway DA. Three-dimensional structure of vaccinia virus-produced human papillomavirus type 1 capsids. JVirol 1994;68:4503-4505.

27.W ang Z, Christensen N, Schilleer JT, Dillner J.A monoclonal antibody against intact human papillomavirus type 16 capsids blocks the serological reactivity of most human sera. J Gen Virol 1997;78:2209-2215.

28. Bousarghin L, Combita-Rojas AL, Touze A, El Mehdaoui S, Sisarte PY, Bravo MM, et al. Detection of neutralizing antibodies against human papillomavirus (HPV) by inhibition of gene transfer mediated by HPV pseudovirions. J Clin Microbiol 2002;40:926-932.

29. Rose RC, Reichman RC, Bonnez W. Human papillomavirus (HPV) type II recombinant virus-like particles induce the formation of neutralizing antibodies and detect HPV-specific antibodies in human sera.J Gen Virol 1994;75:2075-2079.

30. Roden RBS, Hubbert NL, Kirnbauer R, Christensen ND, Lowy DR, Schiller JT. Assessment of the serological relatedness of genital human papillomaviruses by hemagglutination inhibition.JVirol 1996;70:3298-3301. 31.W hite W I,W ilson SD, Bonnez W, Rose RC, Koenig S, Suzich JA. In vitro infection and type-restricted antibody-mediated neutralization of authentic human papillomavirus type 16. J Virol 1998;72:959-964.

32. Giroglou T, Sapp M, Lane C, Fligge C, C hristensen N, Streeck RE et al. Immunological analyses of human papillomavirus capside. Vaccine 2001;19:1783-1793.

33. Combita AL, Bravo MM, Touze A, O rozco O, Coursaget P. Serologic response to human oncogenic papillomavirus types $16,18,31,33,39,58$ and 59 virus-like particles in Colombian women with invasive cervical cancer. Int J Cancer 2002;97:796-803.

34.Andersson-Ellestrom A, Dillner J, H agmar B, Schiller J, Sapp M, Forssman $L$ et al. Comparison of development of serum antibodies to HPV 16 and HPV33 and acquisition of cervical HPV DN A among sexually experienced and virginal young girls. A longitudinal cohort study. Sex Transm D is 1996;23:234-238

35.Touzé A, de Sanjosé S, C ousaget P,Almirall MR, Palacio V, Meijer CJLM et al. Prevalence of anti-human papillomavirus types 16, 18, 31 and 58 virus-like particles in women of the general population and in prostitutes. J Clin Microbiol 2001;39:4344-4348.

36. Shin HR, Lee DH, Herrero R, Smith J, Vaccarella S, Hong SH et al. Prevalence of human papillomavirus infection in women in Busan, South Korea. Int J Cancer 2003;103:413-414.

37. Af G eijerrstam V, Eklund C, W ang Z, Sapp M, Schiller JT, Dillner J. A survey of seroprevalence of human papillomavirus types 16,18 and 33 among children. Int J C ancer 1999;80:2489-2493.

38. Cheng G, Icenogle JP, Kirnbauer R, Hubbert N L, St Louis ME, Han C, Svare El et al. Divergent human papillomavirus type 16 variants are serologically cross-reactive. J Infect D is 1995;172:1548-1587.

39. Touzé A, El Mehdaoui S, Sizaret PY, Mougin C, Muñoz N, C oursaget P. The L1 major capsid protein of human papillomavirus type 16 variants affects the yield of virus-like particle produced in an insect cells expression system. J Clin Microbiol 1998:36:2046-2051.

40. Pastrana DV, Vass W C, Lowy DR, Schiller JT. N HPV16 VLP vaccine induces human antibodies that neutralize divergent variants of HPV 16. Virology 2001;279:361-369.

41. Heino P, Skyldberg B, Lehtinen M, Rantala I, Hagmar H, Kreider JW et al. Human papillomavirus type 16 capsids expose multiple type-restricted and type-common antigenic epitopes. J Gen Virol 1995;76:1141-1153.

42. Rose RC, W hite W I, Li M, Suzich JA, Lane C, Garcea RL. Human papillomavirus type 11 recombinant L1 capsomeres induce virusneutralizing antibodies. JVirol 1998;72:6151-6154.

43. Touzé A, Dupuy C, Mahé D, Siaret PY, Coursaget P. Production of recombinant virus-like particles from human papillomavirus type 6 and 11 , and study of serological reactivities between HPV $6,11,16$ and 45 by
ELISA: Implications for papillomavirus prevention and detection. FEMS Microbiol Lett 1998;160:111-118.

44.Giroglou T, Florin L, Schäfer F, Streeck RE, Sapp M. Human Papillomavirus infection requires cell surface heparan sulfate. JVirol 2001;75:1565-1570. 45. Christensen N D, Kirnbauer R, Schiller JT, C him SJ, Schlegel R, Jenson $A B$ et al. Human papillomavirus types 6 a 11 have antigenically distinct strongly immunogenic conformationally dependent neutralizing epitopes. Virology 1994;205:329-335.

46. Heim K, Christensen N D, Hoepfl R. Serum IgG, IgM, and IgA reactivity to human papillomavirus type 11 and 6 virus-like particles in different gynecologic patient groups. J Infect D is 1995;172:395-402.

47. Ludmerer SW, Benincasa D, Mark GE.Two amino acid residues confer type specificity to a neutralizing, conformationally dependent epitope on human papillomavirus type II. JVirol 1996;70:4791-4794.

48. Christensen ND, Reed CA, Cladel N M, Hall K, Leiserowitz GS. Monoclonal antibodies to HPV-6 L1 virus like particle identify conformational and linear neutralizing epitope on HPV-11 in addition to type specific epitope on HPV-6.Virology 1996;224:477-486.

49. Rose RC, Bonnez W, Da Rin C, McC ance DJ, Reichman RC. Serological differentiation of human papillomavirus types 11,16 and 18 using recombinant virus-like particles. J Gen Virol 1994b;75:2445-2449.

50. N onnenmacher B, Hubbert N L, Kirnbauer R, Shah KV, Muñoz N , Bosch FX et al. Serologic response to human papillomavirus type 16 (HPV 16) virus like particles in HPV 16 DNA positive invasive cervical cancer and cervical intraepithelial neoplasia grade III patients and controls from Colombia and Spain.J Infect D is 1995;172:19-24.

51. C arter J], Koutsky LA, W ipf GC, C hristensen N D, Lee SK, Kuypers J et al.The natural history of human papillomavirus type 16 capsid antibodies among a cohort of university women.J Infect D is 1996;174:927-936.

52. Lehtinen M, Dillner J, Knekt $P$, Luostarinen T,A romaa A, Kirnbauert $R$ et al. Serologically diagnosed infection with human papillomavirus type 16 and risk for subsequent development of cervical carcinoma: nested case control study. Br Med J 1996;312:537-539.

53. de GruijJTD, Bontkes H,W alboomers J, Schiller J, Stukart, G root B et al. Immunoglobulin $\mathrm{G}$ responses against human papillomavirus type 16 viruslike particles in a prospective noninter vention cohort study of women with cervical intraepitheliel neoplasia.J N atl Cancer Inst 1997;89:630-638.

54.Af G eijersstam V, Kibur M,W ang Z, Koskela P, Pukkala E, Schiller J et al. Stability over time of serum antibody levels to human papillomavirus type 16. Infect $D$ is $1998 ; 177: 1710-1714$.

55. Van Doornum $G$, Prins $M$, Andersson-Ellstrom A, Dillner J. Immunoglobulin $A, G$ and $M$ responses to $L 1$ and $L 2$ capsids of human papillomavirus type 6, 16,11,18 and $33 \mathrm{~L} 1$ after newly acquired infection. Sex Transm Infect 1998;74:354-360.

56. W ideroff L, Schiffman MH, N onnenmacher B, Hubbert N L, Kirnbauer $R, G$ reer $C E$. Evaluation of sero-reactivity to human papillomavirus type 16 virus-like particles in an incident case-control study of cervical neoplasia. $J$ Infect $D$ is 1995;172:1425-1430.

57. Carter JJ, Galaway DA. Humoral immune response to human papillomavirus infection. Clin Dermatol 1997;15:249-259.

58. Stanley M. Immune responses to human papillomaviruses. In: Sterling JC, Tyring SK, ed. Human papillomaviruses: $C$ linical and scientific advances. Arnold, Londres: 2001;38-49.

59. Kirnbauer R, Hubbert N L,W heeler C, Lowy DR, Schiller JT.A virus-like particle ELISA detects serum antibodies in a majority of women infected with human papillomavirus type 16.J N atl C ancer Inst 1994;86:498-498. 60. Le Cann P,TouzéA, Enogat N, leboulleux D, Mougin C, Legrand MC et al. D etection of antibodies against the human papillomavirus type 16 virions by means of ELISA using recombinant HPV $16 \mathrm{~L} 1$ capsids produced by recombinant baculovirus. J Clin Microbiol 1995;33:1380-1382.

61. SasagawaT, Inoue M, Lehtinen M,ZangW, G schmeissner SE, Hajibagheri MA et al. Serological responses to human papillomavirus type 6 and 16 virus-like particles in patients with cervical neoplastic lesions. C lin Diagn Lab Immunol 1996;3:403-410. 
62.W ideroff L, Schiffman MH, Haderer P,Armstrong A, G reer CE, Manos MM. Seroreactivity to human papillomavirus type $16,18,31$ and $45 \mathrm{VLP}$ in a case control study of cervical squamous intraepithelial lesions. J Infect Dis 1999;180:1424-1428.

63. Bontkes HJ, de Gruijl TD, W alboomers JM, Schiller JT, Dillner J, Helmerhorst TJ et al. Immune responses against human papillomavirus (HPV) type 16 virus - like particles in a cohort study of women with cervical intraepithelial neo plasia. II. Systemic but not local IgA responses correlate with clearance of HPV-16.J Gen virol 1999;80:409-417.

64. Hisada M, van den Berg Bj, Stricler HD, Chrisrianson RE,W right W E, W aters DJ et al. Prospective study of antibody to human papillomavirus type 16 and risk of cervical, endometrial, and ovarian cancers (United States). Cancer Causes Control 2001;12:335-341.

65. W ideroff L, Schiffman MH, Hoover R, Tarone RE, N onnenmacher B, Hubbert $N$. Epidemiologic determinants of seroreactivity to human papillomavirus (HPV) type 16 virus-like particles in cervical H PV-16 D N Apositive and negative women. J Infect D is 1996;174:937-943.

66. Eisemann C, Fisher SG, G ross G, Müller M, G issmann L.Antibodies to human papillomavirus type 11 virus-like particles in sera of patients with genital warts and in control groups. J Gen Virol 1996;77:1799-1803.

67. C arter JJ,W ipf GC, Hagaensee ME, M CK night B, Habel LA, Lee SK et al. Use of human papillomavirus type 6 capsids to detect antibodies in people with genital warts. I Infect $D$ is 1995;172:11-18.

68. Marais DJ,Vardas E, Ramjee G,Allan B, Kay P, Rose RC et al. The impact of human immunodeficiency virus type 1 status on human papillomavirus (HPV) prevalence and HPV antibodies in serum and cervical secretions. J Infect D is 2000;182:1239-1242.

69. Petter A, Heim K, G uger M, C isera-König, C hristensen N, Sarcletti M M et al. Specific serum IgG, IgM and IgA antibodies to human papillomavirus types $6,11,16,18$ and 31 virus-like particles in human immunodeficiency virus-seropositive women.J Gen Virol 2000;81:701-708.

70. N ewton R, Bousarghin L, Ziegler J, C asabonne D, Beral V, M bidde E et al. Human papillomaviruses and cancer in U ganda. Submitted.

71. Kjaer SK, C hackerian B, van den Brule AJ,Avare El, Paull G,W albomers JM et al. High-risk human papillomavirus is sexually transmitted: Evidence from a follow-up study of virgins starting sexual activity (intercourse). Cancer Epidemiol Biomarkers Prev 2001;10:101-106.

72. Dillner J, Kallings I, Brihmer C, Sikstrom B, Koskela P, Lehtinen M et al. Seropositivities to human papillomavirus types 16,18 or 33 capsids and to chlamydia trachomanis are markers of sexual behavior. J Infect $D$ is 1996;173:1394-1398.

73. Heino P, Eklund C, Fredriksson-Shanazarian V, Goldman S, Schiller JT, Dillner J.Association of serum immuno glo bulin $\mathrm{G}$ antibodies against human papillomavirus type 16 capsids with anal epidermoid carcinoma. J $\mathrm{N}$ atl Cancer Inst 1995b;87:437-440.

74. Bjorge T, Dillner J, Anttila T, Engeland A, Hakulinen T, Jellum E et al. Prospective seroepidemiological study of role of human papillomavirus in non-cervical anogenital cancers. Br Med J 1997;315:646-649.

75. C arter J), Madeleine MM, Shera K, Schwartz SM, C ushing-H augen KL, W ipf GC et al. Human papillomavirus 16 and 18 L1 serology compared across anogenital cancer sites. Cancer Res 2001;61:1934-1940.

76. Muñoz N . Human papillomavirus and cancer: The epidemiological evidence. J Clin Virol 2000;19:1-5.

77.0 Isen A O , D illner J, G joen K, Sauer T, O rstavik I, Magnus P.A populationbased case-control study of human papillomavirus type 16 seropositivity and incident high-grade dysplasia of the uterine cervix. Int J Cancer 1996;68:415-419.

78. Hildesheim A, Han C L, Brinton LA, Kurman RJ, Schiller JT. Human papillomavirus type 16 and risk of preinvasive vulvar cancer: Results from a seroepidemiological case-control study. 0 bstet Gynecol 1997;90:748-754. 79. Hagensee ME, Slavinsky J $3^{\text {rd }}$, G affga CM, Suros J, Kissinger P, Martin $\mathrm{DH}$. Seroprevalence of human papillomavirus type 16 in pregnant women. O bstet Gynecol 1999;94:653-658.

80. Klussmann JP,W eissenborn SJ,W ieland U, D riesV, Kolligs J, Jungehuelsing $M$ et al. Prevalence, distribution, and viral load of human papillomavirus 16 DNA in tonsillar carcinomas. Cancer 2001;92:2875-2884.

81. Giovannelli L, Campisi G, LamaA, Giambalvo 0, 0 sborn J, MargiottaV et al. Human papillomavirus DNA in oral mucosal lesions. J Infect Dis 2002;185:833-836. 